\title{
Anomáliák a hazai pártok pénzügyi ellenőrzésében ${ }^{1}$
}

\section{HORVÁTH ANETT²}

\begin{abstract}
Az Állami Számvevőszék - amely egyedüliként jogosult a pártok fölött gyakorolt pénzügyi ellenörzés megvalósitására - folyamatos törekvése, hogy a pártok és a választások rendszeres törvényességi ellenörzésének tapasztalatai hasznositásával segitse a törvényhozókat, ezért a pártfinanszírozás átláthatóvá tételét célzó törvénymódositási ajánlásait és javaslatait már csaknem másfél évtizede rendszeresen megfogalmazza a kormányzat felé.
\end{abstract}

Kulcsszavak: pártpénzügyi ellenőrzés, pártfinanszírozás, reformok, választási pénzügyek, Állami Számvevőszék, pártpénzügyi ellenőrzés

\section{Anomalies in the Financial Control of Domestic Parties}

The State Audit Office, the sole power to exercise financial control over parties, is constantly striving to assist legislators by utilising the experience of regular scrutiny of parties and elections, and is now making recommendations and proposals for changes to party financing, regularly formulating it to the government.

Keywords: party funding, reforms, transparency, party financial control

\section{Bevezetés}

Jelen tanulmányban igyekeztem a hazai pártok pénzügyeinek ellenőrzésére vonatkozó szabályokat megvizsgálni és a rendszerben fellelhető anomáliákat megvilágítani. Az Állami Számvevőszék - amely egyedüliként jogosult a pártok fölött gyakorolt pénzügyi ellenőrzés megvalósítására - folyamatos törekvése, hogy a pártok és a választások rendszeres törvényességi ellenőrzésének tapasztalatai hasznosításával segítse a törvényhozókat, ezért a pártfinanszírozás átláthatóvá tételét célzó törvénymódosítási ajánlásait és javaslatait már csaknem másfél évtizede rendszeresen megfogalmazza a kormányzat felé.

1 Jelen tanulmány a Jog Állam Politika folyóirat 2020/1. lapszámában megjelent Horváth Anett - Nagy Milán: Pártfinanszírozás címủ tanulmányának rövidített, átdolgozott változata.

$2 \mathrm{PhD}$, az NKE Kormányzástani és Közpolitikai Tanszékének tanársegéde. 
A rendszerváltást követően sem a Párttörvény, sem a választójogi törvény nem határozta meg pontosan a beszámolási kötelezettséget a pártpénzek vonatkozásában: csak a közvélemény tájékoztatását követelték meg a választásra fordított kiadásokról és azok forrásairól. ${ }^{3}$ Annak ellenére, hogy a törvény egyértelműen fogalmazott, miszerint „[m]inden jelöltnek, pártnak a választásokra fordított állami és más pénzeszközök, anyagi támogatások mértékét és a felhasználás módját - országos összesítésben is - a sajtóban nyilvánosságra kell hoznia", ${ }^{4}$ az elvárásnak a jelöltek és a pártok nem tettek eleget. Bár időközben pontosították a rendelkezés megfogalmazását, és a „sajtó” helyett az „országos napilapban” történő tájékoztatás került megfogalmazásra, az 1994. évi országgyűlési választások után mégsem hozta nyilvánosságra a kampányköltéseit egyetlen párt sem. Ugyanakkor felelősségre vonni sem lehetett egyetlen jelöltet és pártot sem, mivel hiányzott a szabályozásból a közvélemény tájékoztatására vonatkozó határidő, illetve a tájékoztatás elmulasztása esetén alkalmazandó szankció is. ${ }^{5}$

\section{Az Állami Számvevőszéki ellenőrzések}

A pártok közhatalomhoz való különleges viszonyából adódik a pártok müködéséről és gazdálkodásáról szóló, többször módosított 1989. évi XXXIII. törvénynek (Pártgazdálkodási törvény) az a garanciális szabálya, hogy valamennyi párt gazdálkodása törvényességének ellenőrzésére a végrehajtó hatalomtól független, az Országgyűlésnek alárendelt szervezet, az Állami Számvevőszék jogosult.

Erre figyelemmel mondja ki továbbá a Pártgazdálkodási törvény azt is, hogy államigazgatási szerv a párt gazdasági, pénzügyi ellenőrzésére nem jogosult. A törvényi rendelkezés alapján az Állami Számvevőszéki ellenőrzések célja mindenkor annak megállapítása, hogy a pártok által készített és a Magyar Közlönyben - 2009-től Hivatalos Értesitóben - közzétett éves beszámolók a törvényi előírásoknak megfelelnek-e, a könyvvezetéssel és a valósággal megegyező adatokat tartalmaznak-e, a könyvvezetés és a gazdálkodás során betartották-e a számvitelről szóló 2000. évi C. törvény (Számviteli törvény) és az egyéb jogszabályok előírásait.

Az ellenőrzés minden esetben kitér annak vizsgálatára is, hogy a párt működéséhez szabályszerűen igénybe vehető forrásokat használt-e fel, nem folytatott-e a Pártgazdálkodási törvény által tiltott gazdálkodó tevékenységet, illetve nem fogadott el tiltott adományt. A számvevők az ellenőrzést minden esetben egységes elvek és eljárások alkalmazásával, az egyes helyszíni ellenőrzésekhez a párt sajátosságaira figyelemmel készített és jóváhagyott ellenőrzési program alapján végzik.

3 Dezső Márta: $A$ választási kampány finanszírozásának koncepcionális kérdései. Budapest, Országos Választási Iroda, 2003. 37-49.

$4 \quad$ 1989. évi XXXIV. törvény az országgyủlési képviselők választásáról (Nem hatályos) IX. fejezet 41. $\mathbb{S}$ (6) bekezdés.

5 Juhász Gábor: Pártpénzügyek. Aula Kiadó, Budapest, 2001. 53. 
A Pártgazdálkodási törvény 10 . $\$$ (3) bekezdése kétévenkénti ellenőrzési kötelezettséget ír elő a rendszeres állami költségvetési támogatásban részesült pártok esetében. A pártok gazdálkodása törvényességének ellenőrzéséhez a számvevőknek olyan mélységű és mértékű ismereteket kell szereznie a pártok szervezetéről és tevékenységéről, amelyek révén azonosítani tudják azokat az eseményeket, ügyleteket és módszereket, amelyek jelentős hatással lehetnek az éves beszámolóra, a vizsgálatra, továbbá a megállapításokra és ezzel összefüggésben a jelentés tartalmára.

Ha az Állami Számvevőszék azt észleli, hogy a párt gazdálkodása körében jogellenesen járt el, felhívja a törvényes állapot helyreállítására. Súlyosabb törvénysértés esetén, vagy ha a párt nem tesz eleget a felhívásnak, az Állami Számvevőszék elnöke indítványozza a bíróság eljárását.

A rendszerváltoztatást követő évtizedek állami számvevőszéki ellenőrzéseinek eredményei és tapasztalatai a pártok gazdálkodása és pénzügyi beszámolói tekintetében egyfajta konstans problémagörbére mutatnak, amely elsősorban a több szempontból sem egyértelmű szabályozásból eredeztethető.

\subsection{Az Állami Számvevőszék szervezete és szerepe a törvények megújításában}

A számvevőszéki ellenőrzés történelmi gyökerei több száz évre visszanyúlnak. Európában 250-300 éve jelentek meg a mai számvevőszékek előzményei először Németországban és Belgiumban. Hazánkban 1870-ben jött létre az Âllami Számvevőszék történelmi elődje. 1914-től működött a Magyar Királyi Legfőbb Állami Számvevőszék (LÁSZ), amelyet 1949-ben megszüntettek és a kormány hatáskörébe került az állami ellenőrzés irányítása és központi szervezete. A rendszerváltoztatás „előestéjén” alkotmánymódosítással újra létrejött az Állami Számvevőszék (ÁSZ) és 1989. október 28-án el is fogadták az 1989. évi XXXVIII. törvényt az Állami Számvevőszékről. Az azóta eltelt több mint két évtized alatt számos törvény szélesítette a Számvevőszék ellenőrzési jogosultságát, illetőleg tovább erősítette függetlenségét.

Az Állami Számvevőszék jogállását meghatározza, hogy a demokratikus jogállam működésének egyik garanciális feltétele a közpénzek és a közvagyon felhasználásának jogszerűsége, átláthatósága és elszámoltathatósága. Az Állami Számvevőszék az állam legfőbb pénzügyi ellenőrző szerve, így az országgyűlés pénzügyi-gazdasági ellenőrző szerve is, tehát a demokratikus államberendezkedés egyik garanciális alapintézménye.

A politikailag és szakmailag független szervezet, amely a közpénzek és a közvagyon hasznosítását ellenőrzi, ellenőrzéseit utólagosan törvényességi, célszerűségi és eredményességi szempontok szerint végzi. Függetlenségének biztosítékai, hogy csak az országgyülésnek és a törvényeknek alárendelt, valamint az Állami Számvevőszékről szóló törvény elfogadásához a jelen lévő képviselők kétharmadának igen szavazata kell. A megválasztott elnök és az alelnökök mentelmi joggal is rendelkeznek, politikai 
tevékenységet nem fejthetnek ki, valamint szigorú összeférhetetlenségi előírások és vagyonnyilatkozat-tételi kötelezettségek is vonatkoznak rájuk.

Az Állami Számvevőszék küldetése, hogy szilárd szakmai alapon álló, értékteremtő ellenőrzéseivel előmozdítsa a közpénzügyek átláthatóságát, rendezettségét és hozzájáruljon a „jó kormányzáshoz”. A számvevőszéki ellenőrzések mindenkori további célja, hogy hozzáadott értéket teremtsen, közpénzt takarítson meg, kezdeményezze a szükséges változtatásokat és az ellenőrzések során tapasztalt „legjobb gyakorlatokat" széles körben megismertesse és terjessze.

A számvevőszéki ellenőrzések tehát kiterjednek a teljes államháztartásra, az államkincstári és vállalkozói vagyonára, az államháztartáson kívüli egyes szervezetek gazdálkodására, az országgyülésnek beszámolási kötelezettséggel tartozó intézmények müködésére, az állami költségvetésből nyújtott támogatás, illetve az állam által meghatározott célra ingyenesen juttatott vagyon felhasználására és a pártok gazdálkodásának törvényességére.

Az Állami Számvevőszék eszközei és jogosultságai alapján javaslatot tesz a jogi szabályozásra, felhív a törvényes állapot helyreállítására, kezdeményezi a szabálytalanul felvett pénzek visszafizettetését, személyi felelősségre vonást. Javasolhatja továbbá a Közbeszerzési Döntőbizottság eljárását, büntetőfeljelentést tesz bűncselekmény alapos gyanúja esetén, zároltathat anyagi eszközöket pazarló felhasználás esetén, felfüggesztheti a költségvetési finanszírozást beruházások esetén, kármegelőzés céljából. ${ }^{6}$

Az Országgyủlés az Alaptörvénnyel és az Állami Számvevőszékről szóló törvénynyel biztosítja a közpénzzel és a közvagyonnal való gazdálkodást vizsgáló legfőbb ellenőrző szervezet szervezeti, jogi, személyi és pénzügyi függetlenségét, az Âllami Számvevőszék külső befolyástól mentes müködését. Az Állami Számvevőszék függetlenségének garanciális elemei az alábbiak szerint jelennek meg a vonatkozó törvényi előírásokban: 1. A szervezeti függetlenség: az Állami Számvevőszék ellenőrzési tevékenysége során minden más szervezettől független. Az Állami Számvevőszék elnökét az Országgyủlés az országgyűlési képviselők kétharmadának szavazatával 12 évre választja meg. Az Állami Számvevőszék hivatali szervezeti rendben mủködik. Az Állami Számvevőszék elnöke széles körü, önálló szervezetalakító jogosítványnyal rendelkezik. 2. A jogi függetlenség: az Állami Számvevőszék általános hatáskörrel végzi a közpénzekkel, valamint az állami és az önkormányzati vagyonnal való felelős gazdálkodás ellenőrzését. Az Állami Számvevőszék feladatait az Alaptörvény, az Állami Számvevőszékről szóló törvény és más törvények állapítják meg. Az Âllami Számvevőszék tevékenységét ellenőrzési terv alapján végzi, amit az elnök hagy jóvá. Az ellenőrzési tervről és annak módosításáról az Állami Számvevőszék elnöke tájékoztatja az Országgyűlést. Az Állami Számvevőszék a működését, feladatait közvetlenül meghatározó törvényeket véleményezi. Az Állami Számvevőszék ellen-

6 Az Állami Számvevőszék szervezete és működése c. konferencia Domokos László, az ÁSZ elnökének előadásán készített saját feljegyzésekből. Budapest, Budapesti Corvinus Egyetem, 2011. február 23. 
őrzésszakmai szabályait a legfőbb ellenőrző intézmények nemzetközi standardjai figyelembevételével maga alakítja ki, és a kialakított szabályokat nyilvánosságra hozza. Az Állami Számvevőszék jelentései, az abban foglalt megállapításai, következtetései bíróság vagy más hatóság előtt nem támadhatók meg. 3. A pénzügyi függetlenség: az Állami Számvevőszék a központi költségvetés szerkezetében önálló fejezet, a fejezet felügyeletét ellátó szerv vezetőjének jogosítványait az elnök gyakorolja. Az Állami Számvevőszék a költségvetésére vonatkozó javaslatát és a költségvetésének végrehajtásáról szóló beszámolóját maga állítja össze és azt a kormány változtatás nélkül terjeszti be a központi költségvetésről, illetve az annak végrehajtásáról szóló törvényjavaslat részeként az országgyűlésnek. Az Állami Számvevőszék költségvetését úgy kell megállapítani, hogy az nem lehet kevesebb az előző évi központi költségvetésben megállapított összegnél. Az Állami Számvevőszék részére az Állami Számvevőszékről szóló törvényen túlmenően további feladatot törvény csak úgy állapíthat meg, hogy a feladatellátáshoz szükséges pénzügyi fedezetet egyidejủleg biztosítja. A számvevői illetményrendszer független a közalkalmazottak és köztisztviselők illetményrendszerétől, a számvevői illetmények a Központi Statisztikai Hivatal által hivatalosan közzétett nemzetgazdasági havi átlagos bruttó keresethez igazodnak. 4. A személyi függetlenség: Az abszolút összeférhetetlenség: Nem jelölhető az Állami Számvevőszék elnökévé olyan személy, aki a megelőző négy évben tagja volt a kormánynak, vagy bármely párt országos (központi) szervezetében választott vezető tisztséget töltött be. Az Âllami Számvevőszék elnökét az országgyűlési képviselővel azonos mentelmi jog illeti meg.

Az Állami Számvevőszék folyamatos törekvése, hogy a pártok és a választások rendszeres törvényességi ellenőrzésének tapasztalatai hasznosításával segítse a törvényhozókat, ezért a párt- és kampányfinanszírozás átláthatóvá tételét célzó törvénymódosítási ajánlásait és javaslatait már csaknem másfél évtizede rendszeresen megfogalmazza a kormányzat felé. Általánosságban elmondható, hogy a pártok törvény által elöírt éves pénzügyi beszámolója - az elmúlt két és fél évtized tapasztalatai alapján - nem biztosítja megfelelően a gazdálkodás átláthatóságát, összehasonlíthatóságát és értékelhetőségét.

Ennek elsődleges oka, hogy a többszöri módosítások ellenére a Pártgazdálkodási törvény elöírásai továbbra sincsenek összhangban a Számviteli törvény egységes követelményeivel, illetve a választások finanszírozása továbbra sem különül el a pártok gazdálkodásától, hiányoznak a zártság és az azonosíthatóság garanciális szabályai, továbbá nincs előírás a források és felhasználások közlésére sem. A pártok pénzügyi beszámolói a törvényi előírásoknak megfelelően a bevételi és a kiadási oldalon a következő mérlegsorokat tartalmazzák (1. táblázat). ${ }^{7}$

7 Az 1992. január elsején életbe lépett Számviteli törvény hatálya kiterjedt a pártokra is. A Párttörvényt módosító 1992. évi LXXXI. törvény megváltoztatta az előző évi gazdálkodásról a Magyar Közlönyben közzéteendő beszámolók tartalmát. 
1. táblázat: A pártok beszámolóinak tartalma

\begin{tabular}{|c|c|}
\hline Bevételek & Kiadások \\
\hline Tagdíjak & $\begin{array}{l}\text { Támogatás a párt országgyúlési } \\
\text { csoportja számára }\end{array}$ \\
\hline Állami költségvetésből származó támogatás & Támogatás egyéb szervezeteknek \\
\hline Képviselői csoportnak nyújtott állami támogatás & $\begin{array}{l}\text { Vállalkozások alapítására fordított } \\
\text { összegek }\end{array}$ \\
\hline $\begin{array}{l}\text { Egyéb hozzájárulások, adományok } \\
\text { Jogi személyektől: } \\
\text { Belföldiektől (az } 500 \text { ezer Ft feletti támogatás nevesítve) } \\
\text { Külföldiektől (a } 100 \text { ezer Ft feletti támogatás nevesítve) } \\
\text { Jogi személynek nem minősülő gazdasági társaságtól: } \\
\text { Külföldiektől (a } 100 \text { ezer Ft feletti támogatás nevesítve) } \\
\text { Magánszemélyektől: } \\
\text { Belföldiektől (az } 500 \text { ezer Ft feletti támogatás nevesítve) } \\
\text { Külföldiektől (a } 100 \text { ezer Ft feletti támogatás nevesítve) }\end{array}$ & Müködési kiadások \\
\hline $\begin{array}{l}\text { A párt által alapított vállalat és korlátolt felelősségủ } \\
\text { társaság nyereségéből származó bevétel }\end{array}$ & Eszközbeszerzés \\
\hline \multirow[t]{2}{*}{ Egyéb bevétel } & Politikai tevékenység kiadása \\
\hline & Egyéb kiadások \\
\hline
\end{tabular}

Forrás: a szerző szerkesztése

Az Állami Számvevőszék javaslataiban többször megfogalmazta a pártok pénzügyi beszámolójához kapcsolódó törvényi változtatások szükségességét, amelyek megteremthetnék a lehetőségét egy átlátható gazdálkodási-ellenőrzési mechanizmus kialakításának. Az Állami Számvevőszék jogszabály-változtatási javaslatai szerint szükséges a Pártgazdálkodási törvény és a Számviteli törvény összhangjának megteremtése, a mérleg, az eredménykimutatás és a kiegészítő tájékoztató rendszerű beszámoló elkészítésének és közzétételének követelménye. További általános tapasztalat, hogy a pártok nagy többsége elmulasztja határidőben közzétenni előző évi gazdálkodási beszámolóját, és ezek a közzétett beszámolók többségükben nem felelnek meg a megbízhatóság és valódiság számviteli követelményének. A tiltott bevételszerzés kapcsán a költségvetési támogatásra nem jogosult pártok a jelenlegi szabályozás szerint mentesülnek a kétszeres költségvetési alapba befizetés alól. A jelenleg hatályos szabályozás csak az állami támogatás azonos összegü csökkentéséről rendelkezik.

Az Állami Számvevőszék további rendszeres indítványai a pártok kampánytevékenységéhez köthető. A bejelentett kampányszámla kötelezővé tétele a választási célú bevételek és kiadások elkülönített, teljes körű elszámolásához. Plakátok egyedi azonosíthatósága, politikai hirdetések szabályozása, gyülések bejelentése stb. A tiltott kampánytevékenység és -finanszírozás meghatározása és visszatartó erejü büntetése. Számvevőszéki hatáskör bővítése és az elszámolási követelmények részletes törvényi 
szabályozása. Az Állami Számvevőszék javaslataiban megfogalmazottak alátámasztására találhatunk nemzetközi „jó” példákat is (2. táblázat). ${ }^{8}$

\section{2. táblázat: Nemzetközi „jó példák”"}

\begin{tabular}{|c|c|}
\hline $\begin{array}{c}\text { Pártok gazdálkodása, a kampányfinanszírozás } \\
\text { összehangoltan szabályozott }\end{array}$ & Kanada \\
\hline Elkülönített kampányszámla & Franciaország, Oroszország \\
\hline Kampányköltség korlátozása & Franciaország \\
\hline Ingyenes médiaszereplés & Egyesült Királyság \\
\hline $\begin{array}{c}\text { „Harmadik oldal” kampányának szabályozása, korlátozása, } \\
\text { elszámolása }\end{array}$ & Németország \\
\hline Készpénzadomány értéke korlátozott & Németország, Belgium \\
\hline Állami támogatás elvonása pénzügyi beszámoló hiányában & Olaszország \\
\hline Büntetőjog alkalmazása & \\
\hline
\end{tabular}

Forrás: Horváth i.m. (9. lj.)

Az Állami Számvevőszék hosszú évek óta fenntartott álláspontja szerint a törvények módosítása közös, társadalmi érdek a korrupció visszaszorítása és a társadalmi fejlődés okán. Az Állami Számvevőszék érdeke pedig egy átlátható, ellenőrizhető és elszámoltatható rendszer kialakítása.

\subsection{Az állami számvevöszéki ellenörzések általános tapasztalatai}

Az ellenőrzések tapasztalataiból általánosságban megállapítható, hogy a vizsgált pártok egyikének sem volt megfelelő, teljes körü és minden szempontból pontos pénzügyi zárómérlege a rendszerváltoztatás óta eltelt csaknem két és fél évtizedben. Pártonként vizsgálva azonban változatos kép rajzolódik ki. A kisebb pontatlanságtól a mérleg valamennyi sorának, adatának - kivéve az állami költségvetési támogatás összegét - a tényleges állapottól való drasztikus eltéréséig mindennel találkozhattunk. Több zavart okozott a pénzügyi beszámolók készítése kapcsán, hogy nem volt egyértelmű a szabályozás és szakmailag vitatható volt a Pártgazdálkodási törvényben előírt pénzügyi zárómérleg tartalma is. Ennek következtében a pártok a pénzügyi zárómérlegeiket nem tudták valamennyi pártra nézve egységesen elkészíteni. A közzétett mérlegadatok ezért sok esetben csak nehézkesen hasonlíthatók össze egymással. Ugyanakkor a vizsgálatok egyes helyeken a szakértelem hiányából, a könyvvezetés

8 A táblázat szemléltető jellegű, terjedelmi és lehatárolási korlátok miatt, a szabályozás és ellenőrzés nemzetközi mintáival részleteiben nem kívántam foglalkozni.

9 Lásd bővebben: Horváth Balázs: A pártok mőködésének, gazdálkodásának és a kampányfinanszírozásnak a szabályai a számvevőszéki ellenörzések tükrében. 2011. Elérhető: www.asz.hu/storage/ files/files/Publikaciok/Horvath_Balazs/partfinanszirozas.pdf?download=true (A letöltés dátuma: 2020. 09. 18.) 
rendezetlenségéből, a helyi szervezetek gazdálkodási adatait tartalmazó részjelentések nem megfelelő összegzéséből adódó, a tényleges állapottól eltérő adatok szerepeltetését is több ízben tapasztalta. A közvélemény megfelelö tájékoztatását, a nyílt áttekinthetőséget szolgálja a Pártgazdálkodási törvény mérleg közzétételére vonatkozó garanciális szabálya. A pártok azonban többször elmulasztották a megfelelő határidőben történő közzétételt is. A Pártgazdálkodási törvény nem szankcionálta azokat az eseteket - eltérően a tiltott pénzforrások igénybevételétől -, amikor szabálytalan gazdálkodási tevékenységet végzett a párt, és ennek következtében jutott bevételhez. A felügyeleti szerv ennek a kérdéskörnek a rendezését is a Pártgazdálkodási törvény módosításával látta feloldhatónak.

A Pártgazdálkodási törvény értelmében az Állami Számvevőszék által alkalmazható jogi eszköz, a törvényességi felhívás, csak a tiltott tevékenység felhagyására irányulhatott. Az Állami Számvevőszék az ellenőrzési megállapításait nem nyomozó hatóságként, hanem az ellenőrzött szervezetek által rendelkezésére bocsátott, hiteles dokumentumok alapján tette és teszi napjainkban is. A felügyeleti szerv a törvényi előírás értelmében kétévenként minden olyan Magyarországon mủködő párt gazdálkodásának törvényességét ellenőrzi, amely az adott két évben a központi költségvetésből rendszeres támogatásban részesült. A 2011-ben hatályba lépett új Állami Számvevőszéki törvény értelmében a pártok intézkedési terv elkészítésére is kötelezettek.

\subsection{Az ellenörzések hatásosságát növelö lehetséges intézkedések}

A pártok gazdálkodásának vizsgálatára hivatott Állami Számvevőszék elvileg alkalmas, gyakorlatilag azonban hajlandóságának hiánya okán a lefolytatott vizsgálataik eredménye valójában csak korlátozott eredmények megismerését teszik lehetővé. A szabályozás szűkszavúsága lehetővé teszi az Állami Számvevőszék aktívabb hozzáállását is, de a szervezet saját hatáskörére a lehető legszükítőbb értelmezést követi és követte mindenkor, aminek oka vélelmezhetően az, hogy mindenképp elkerülné a politika befolyásolásának lehetőségét. Valójában azonban nem is az ellenőrzési konstrukció szorul változtatásra, mert a még 1989-ben kialakított intézményi struktúra működőképes. A kontrollt olyan szervezet végzi, amely közvetlenül a parlamentnek, nem pedig a kormánynak alárendelt és az Állami Számvevőszéknek ezen a területen nincs alternatívája. Az Állami Számvevőszék feladat- és hatásköréről rendelkező törvény kétharmados támogatottságot igényel, ahogy az elnök megválasztásához is hasonló többség szükséges. A számvevőszék vezetőit a magyar közjogban példátlanul hosszú időre, 12 évre választják, és emiatt más főtisztviselőknél több lehetőségük van függetleníteni magukat a politikai széljárástól. A legitimitás és a függetlenség garanciája tehát adott, a létező struktúra azonban reformra és bővítésre szorul, mert a pártok számvevőszéki ellenőrzése jelenleg egy lassú, gyakorlatilag csak egy utólagos könyvelési kontrollnak felel meg. 
Az Állami Számvevőszék azonban nem hatóság, legfeljebb javaslatot tehet, amit a törvény(ek) keretein belül mindig meg is tett/tesz, ennek a javaslattételi jogkörnek a további szélesítése az, ami továbbgondolásra is érdemes lehet. A mai szabályozási feltételek mellett azonban, amikor az előírások egy részének kötelező ereje " $a b$ ovo” kétséges (például Pártgazdálkodási törvény 2. sz. melléklete), kérdés, hogy lehetséges-e érdemi javaslatokat megfogalmazni?

A hivatkozott szakmai mủhelykonferencián ${ }^{10}$ elhangzott egyes észrevételek, javaslatok rendszerbe emelése azonban - úgy gondolom -, hogy bizonyos elemeiben mégis megfontolásra érdemesek lehetnek, mert az átláthatóság és elszámoltathatóság irányába hatnának:

a) egy létszámában és felkészültségében is megerősített intézményi struktúra kialakítása,

b) az állami támogatásból részesülő pártok kétévenként sorra kerülő vizsgálatának éves rendszerű ellenőrzésre változtatása,

c) a soron kívüli (azonnali), vizsgálat lehetőségének megteremtése,

d) a vizsgálat előtti értesítés eltörlése és

e) a pártközpontok könyvelésének ellenőrzése mellett, a pártok üzleti vállalkozásai, alapítványai és ifuúsági szervezetei ellenőrzésének beemelése, valamint

f) az ÁSZ bírságolási és nyomozati jogkörének kiszélesítése.

\section{3. Összegzés}

Jelen tanulmányban igyekeztem rávilágítani a kampányfinanszírozás és a hozzá kapcsolódó pártpénzügyi beszámolók és ellenőrzések között fennálló anomáliákra, illetve arra, hogy az átláthatóság vagy annak hiánya milyen problémákat jelent a folyamatban. Megvizsgáltam, hogy az Állami Számvevőszék, amely a pártpénzügyi beszámolók ellenőrzését végzi, és a tevékenységét behatároló tényezők miképpen világítanak rá a problémákra, és jelzik, hogy e problémák megoldására tett kísérletek folyamatosak, de sokszor hatékonyságuk mégis megkérdőjelezhető.

\section{Irodalomjegyzék}

Az Állami Számvevöszék szervezete és müködése c. Konferencia Domokos László, az ÁSZ elnökének elöadásán készitett saját feljegyzésekből. Budapest, Budapesti Corvinus Egyetem, 2011. február 23.

Dezső Márta: A választási kampány finanszírozásának koncepcionális kérdései. Budapest, Országos Választási Iroda, 2003.

Juhász Gábor: Pártpénzügyek. Budapest, Aula, 2001.

10 Átláthatóságot és elszámoltathatóságot a párt- és kampányfinanszírozásba! c. Műhelykonferencia előadásain elhangzott adatok feldolgozásával. Budapest, 2009. április 29. 


\section{Internetes forrás}

Horváth Balázs: A pártok möködésének, gazdálkodásának és a kampányfinanszírozásnak a szabályai a számvevıszéki ellenırzések tükrében. 2011. Elérhető: www.asz.hu/storage/files/files/Publikaciok/Horvath_Balazs/partfinanszirozas.pdf?download=true (A letöltés dátuma: 2020. 09. 18.)

\section{Jogi források}

2018. évi XXXVI. törvény egyes választásokkal kapcsolatos törvények módosításáról

2017. évi CLX. törvény az országgyülési képviselők választása kampányköltségeinek átláthatóvá tételéről szóló 2013. évi LXXXVII. törvény módosításáról

2013. évi LXXXVII. törvény az országgyűlési képviselők választása kampányköltségeinek átláthatóvá tételéről

1997. évi C. törvény a választási eljárásról

1989. évi XXXIV. törvény az országgyűlési képviselők választásáról 